\title{
Durum wheat and allelopathy: toward wheat breeding for natural weed management
}

\author{
Mariagiovanna Fragasso, Anna lannucci and Roberto Papa* \\ Consiglio per la Ricerca e la Sperimentazione in Agricoltura, Cereal Research Centre, Foggia, Italy
}

Edited by:

Paul Christiaan Struik, Wageningen

University, Netherlands

Reviewed by:

Juan B. Alvarez, Universidad de

Córdoba, Spain

Soren K. Rasmussen, University of

Copenhagen, Denmark

*Correspondence:

Roberto Papa, Consiglio per la Ricerca e la Sperimentazione in Agricoltura,

Cereal Research Centre, S.S. $16 \mathrm{Km}$

675, 71122 Foggia, Italy

e-mail: roberto.papa@entecra.it
Wheat-derived foodstuffs represent about one-fifth of the calories consumed by humans worldwide. Bread wheat (Triticum aestivum L.) is one of the most important crops throughout the world, and it has been extensively studied for its allelopathic potential. In contrast, for allelopathy in durum wheat (Triticum turgidum ssp. durum), our knowledge is partial and fragmentary. Through highlighting recent advances in using allelopathy as a cropbreeding tool, we provide an overview of allelopathy in Triticum spp., to stimulate further coordinated breeding-oriented studies, to favor allelopathy exploitation for the sustainable cultivation of wheat, and in particular, to achieve improved biological weed control.

Keywords: allelopathy, wheat, durum wheat, allelochemical, crop allelopathy, weed management, sustainability

\section{INTRODUCTION}

Competition among plants has been divided into two different biological phenomena: competition in terms of the "removal" of shared or limited resources, such as space, light, water, and/or nutrients; and allelopathy, in terms of chemical interactions between plants (Olofsdotter et al., 2002). Allelopathy appears to have been first noted by the Greek philosopher and botanist Theophrastus as early as 2300 BP (Weir et al., 2004), and it is defined as "the inhibitory effect of a plant (donor) on other plants (receivers) through the release of toxic chemicals produced by the donor plant into the environment that affect a receiving susceptible species" (Olofsdotter et al., 2002). These competitive abilities are genetically controlled and can be affected by the environment in which a plant grows (Olofsdotter et al., 2002). Chemical compounds that have allelopathic effects can have adaptive roles, such as for plant defense and nutrition, and soil fertility (as in the regulation of the soil biota, which affects the organic matter decomposition; Inderjit et al., 2011). Scientific attentiveness to allelopathy as a crop-breeding tool is a consequence of the economic relevance associated with: (i) the development of herbicide-resistant populations in key weed species (Worthington and Reberg-Horton, 2013); (ii) the need for improved weed suppression in organically grown cereals (Hoad et al., 2012); and (iii) the need for low cost weed control for smallholder farmers, especially in developing countries (Toure et al., 2011). For these reasons, an advance in allelopathic potential in crop varieties might have a remarkable impact on both low-input and high-input agricultural management systems (Kim and Shin, 2003).

With 620 million tons of wheat grain produced annually worldwide, wheat represents about one-fifth of the calories consumed by humans (United Nations, 2006). Roughly $95 \%$ of this wheat is obtained from the hexaploid species Triticum aestivum L. ssp. aestivum (bread wheat), which is used for making bread, cookies and pastries; the remaining $5 \%$ is obtained from the tetraploid durum wheat (Triticum turgidum ssp. durum Desf. em. Husn.).
Bread wheat is also the main ingredient for pizza, and several cake doughs. The European Union, China, India, The United States of America, and the Russian Federation are the main wheat producers (FAO, 2011). Durum wheat is used for the production of pasta, semolina, and couscous, and in some areas of the world, also for various types of bread. The major durum wheat production areas are in the European Union (e.g., it is the main cereal crop in Italy), Canada, Syria, The United States of America, Algeria, and Morocco, and the minor production areas include the Russian Federation, Turkey, Tunisia, Mexico, and India (De Vita et al., 2007a,b).

In this mini review, we explore the present knowledge of wheat allelopathy, to illustrate its potential for the control of weeds. We underline the partial and fragmentary evidence, particularly in the case of durum wheat. The aim is thus to stimulate further coordinated breeding-oriented studies and to favor allelopathy exploitation for the sustainable cultivation of wheat.

\section{CEREAL ALLELOPATHY IN A BREEDING-ORIENTED PERSPECTIVE}

A breeding-oriented framework of allelopathy studies requires the characterization of the genetic basis of allelopathy and its diversity, along with the definition of the breeding strategies. In 1996, the International Allelopathy Society includes in allelopathic phenomena any process involving secondary metabolites produced by plants, microorganisms, algae, and fungi that influence the growth and development of agricultural and biological systems. Allelopathy is associated with the release of chemical compounds from plants that "suppress the growth and establishment of other plants in their vicinity" (Inderjit et al., 2011), determining the patterning densities and distribution of various species. In addition, these chemicals can help plants to reinforce their protection system against biotic and abiotic stress, and to promote the regulation of nutrient transformation and absorption, and soil fertility (Inderjit et al., 2011; Jabran and Farooq, 
2013). Thus, allelopathy might have a significant role in the determination of the diversity of plant communities (Inderjit et al., 2011). To exemplify the adaptive role of allelopathy, Putnam and Duke (1974) observed in cucumber that the ancestors of the present crops possessed high allelopathic activity. However, standard agronomic practices (e.g., herbicide application) have reduce the need for competition with weeds and the associated selection pressure in plant breeding programs, which could thus explain the competitive loss in the modern cultivar (Bertholdsson, 2004; Wolfe et al., 2008). In contrast with this trend, in an analysis of Swedish wheat cultivars, Bertholdsson (2007) underlined how landraces and old cultivars were less allelopathic than modern varieties.

From a breeding perspective (Bertholdsson, 2005; Weih et al., 2008; Prohens, 2011), the application of genomic approaches is crucial for the identification and characterization of genes with ecological and evolutionary relevance (Ungerer et al., 2008). Effectively, cereal crops including rice, sorghum, wheat, rye, maize, and barley, show strong allelopathic activities, with the potential for identification of the molecular dissection of this trait to promote allelopathy-oriented crop improvements (Jabran and Farooq, 2013). For many major crop species (e.g., rice, wheat, oat, barley, rye), a high level of genotypic differences is seen within species (Fay and Duke, 1977; Burgos et al., 1999; Ahn and Chung, 2000; Wu et al., 2000b, 2001b; Bertholdsson, 2004; Jung et al., 2004; Seal et al., 2004; Ahn et al., 2005; Grimmer and Masiunas, 2005; Ma, 2005; Reberg-Horton et al., 2005; Zuo et al., 2007; Saffari and Torabi-Sirchi, 2011).

Enhancement of the competitive ability of a crop for weed suppression through allelopathic potential using plant breeding requires efficient phenotyping strategies, both at field evaluation and under controlled conditions. Indeed, to undertake a breeding program, a good screening technique needs to be developed, the genetic variability for the target trait should be accessible in the germplasm, and the genetic control of the desired phenotype should be defined.

In the following sections, we briefly review the case for wheat: the weed competitive arena, the allelopathy phenomena, and some genetic aspects.

\section{THE WHEAT/WEED ENVIRONMENT}

Weeds are responsible for heavy yield losses in wheat because of their competition for water, nutrients, and light, and also, as shown for Avena fatua L. (wild oats), for their toxic effects. The distribution of grass weeds in cereal crops is usually patchy. Such weed patches can be quite steady over a number of growing cycles, as can weeds such as wild oat, that can cause a $2 \%$ yield loss in cereal crops even at low density (one or two plants per $\mathrm{m}^{2}$; Carrara et al., 2004). Herbicide treatments achieve the best results in terms of reducing the weed biomass, followed by hoeing and harrowing (Garcì-Martìn et al., 2007). Even if durum wheat responds differently to some herbicides compared to bread wheat, using conventional farming systems, both crop species require the application of considerable quantities of herbicides, with the same amounts spread throughout the field (Soltani et al., 2011). These are necessary to control the major monocotyledonous and dicotyledonous weeds, such as Avena fatua L. (wild oat), Lolium perenne L. (annual ryegrass), Phalaris spp. L. (canary grass), Alopecurus myosuroides Huds. (blackgrass), and Galium aparine L. (cleaverwort; Barberi et al., 1997; Carrara et al., 2004; Bertholdsson et al., 2012), as reported by Garcìa-Martìn et al. (2007) and Barberi et al. (1997).

The other most widespread weeds in wheat crops are reported in Table 1. This list is of particular interest as a reference if we consider that in an experimental design of allelopathic studies, it is important to conveniently select a panel of weeds that are locally relevant (as receiver species), as a function of the induced losses in wheat production, and thus of the economic significance (Worthington and Reberg-Horton, 2013).

\section{ALLELOPATHY AND WHEAT}

Table 2 summarizes the various investigations into wheat allelopathy, to the best of our knowledge. Studies on bread wheat allelopathy have included: (i) allelopathy against other crops, weeds (Wu et al., 1999, 2000a,b, 2001a); (ii) isolation and identification of allelopathic agents (Wu et al., 2001a,b,c); (iii) wheat autotoxicity (Wu et al., 2001a, 2007a); (iv) management of residues (Wu et al., 2001a); and (v) genetic variations and genetic markers (Wu, 2005; Wu et al., 2008).

Along these lines, the allelopathic activities of wheat varieties change with respect to the major weeds, which indicates the possibility to exploit this characteristic for the selection of allelopathic varieties to be used in integrated weed management. Some of the classes of allelochemicals for wheat allelopathy have also been defined, such as phenolic acids, hydroxamic acids, and short-chain fatty acids. Also, when wheat straw remains on the soil surface, the undesirable impact of the resultant wheat autotoxicity on agricultural production has been noted (for reviews, please see Wu et al., 2001a, 2008).

In contrast, very little is known about durum-wheat allelopathy. In consideration of allelopathy against other crops, Oueslati (2003) studied the two durum-wheat varieties that are commonly used in northern Tunisia, and tested these for toxicity (heterotoxicity) against bread wheat and barley, with an evaluation of the allelopathic potential of various parts of the durum-wheat plants. This study highlighted the role of durum wheat as a donor plant, that may constitute a risk to crop sequences. Additionally, it has been demonstrated that the allelopathy of durum wheat varies with the source of the extracts, whereby the leaf extracts are the most active. This is in agreement with evidence from bread wheat, where aqueous extracts from residues were shown to suppress barley growth (Hozumi et al., 1974). Here, the negative effects of bread wheat residue allelopathy on the growth of other crops were also shown to vary across wheat varieties (Wu et al., 2001a). Indeed, as also shown by Oueslati (2003), the two durum-wheat varieties tested can lead to slight differences in allelopathic effects on barley and bread wheat. Recently, Fragasso et al. (2012) determined the tolerance of seven durum-wheat cultivars to the allelopathic potential of the rhizosphere soil of wild oat. This study was performed in a growth chamber, using durum-wheat varieties that were seeded and grown in control (non-rhizosphere) soil and rhizosphere soil of wild oat. The results showed that the degree of inhibition is more evident for the leaves than for root growth, and that it is cultivar dependent. 
Table 1 | A list of widespread weeds in wheat crops, with their scientific names, common names, and global geographical distributions. The global distribution is reported in accordance with the AgroAtlas (Afonin et al., 2008; http://www.agroatlas.ru/; n.r., not reported in the AgroAtlas).

\begin{tabular}{|c|c|c|}
\hline Scientific name & Common name & Global geographical distribution \\
\hline Achillea millefolium L. & Bloodwort & Europe; Asia, Japan, China; Northern America; Australia, and New Zealand \\
\hline Amaranthus retroflexus L. & Careless weed & $\begin{array}{l}\text { North and South America; middle and southern Europe; Mediterranean area; Asia Minor; } \\
\text { Iran; China; Japan; Mongolia; northern Africa }\end{array}$ \\
\hline Anagallis arvensis L. & Scarlet pimpernel & n.r. \\
\hline Anthemis arvensis L. & Corn chamomile & European part of Russia, Caucasus; Siberia, Central Asia; Scandinavia, Mediterranean \\
\hline Avena sterilis L. & Animated oat & n.r. \\
\hline Capsella bursa-pastoris L. & Shepherd's purse & Cosmopolitan (this weed is found in all parts of the world except tropical regions) \\
\hline Cardamine hirsuta L. & Hairy bittercress & n.r. \\
\hline Chenopodium album L. & Common lambsquarters & Cosmopolitan (this weed is found in all parts of the world) \\
\hline Cichorium intybus L. & Chicory & n.r. \\
\hline Cirsium arvense (L.) Scop & Creeping thistle & Europe; Western Asia; North America \\
\hline Convolvulus arvensis L. & Field bindweed & $\begin{array}{l}\text { Almost cosmopolitan (Far East, Central Asia, Western Europe, Asia, Northern Africa, } \\
\text { Northern and South America) }\end{array}$ \\
\hline Equisetum arvense L. & Field horsetail & $\begin{array}{l}\text { Europe, Caucasus, Siberia, the Himalaya, Central China, Japan; North America; New } \\
\text { Zealand }\end{array}$ \\
\hline Lactuca serriola L. & Prickly lettuce & Western Europe (southward of 55 degrees latitude); western Asia; northern Africa \\
\hline Malva sylvestris L. & Common mallow & n.r. \\
\hline Polygonum aviculare L. & Prostrate knotweed & Cosmopolitan (this weed is found in all parts of the world) \\
\hline Polygonum persicaria L. & Smartweed & n.r. \\
\hline Rumex crispus L. & Curly dock & Europe; North Africa; Turkey; northern Iran, eastern-central Asia; North America \\
\hline Rumex obtusifolius L. & Bitter dock & n.r. \\
\hline Silene inflata Sm. & Catchfly & n.r. \\
\hline Sinapis arvensis ssp. arvensis & Wild mustard & Europe; North Africa; Asia Minor, Iran, Afghanistan; North America \\
\hline Silybum marianum (L.) Gaertn. & Milk thistle & n.r. \\
\hline Solanum nigrum L. & Black nightshade & $\begin{array}{l}\text { European part of the Former Soviet Union, the Caucasus,. Distributed also in } \\
\text { Scandinavia, Europe, Mediterranean; Central Asia, Siberia, Far East, Iran, India, } \\
\text { China, Japan; North Africa; North America }\end{array}$ \\
\hline Sonchus asper L. (Hill) & Prickly sowthistle & $\begin{array}{l}\text { Almost allWestern Europe, Asia Minor, Iran, Afghanistan, the Himalaya, Mongolia, South } \\
\text { and East Asia, North and South America, Australia }\end{array}$ \\
\hline Stellaria media L. & Common chickweed & Europe; Asia; North America \\
\hline Vaccaria hispanica (Mill) Rauschert & Cowherb & n.r. \\
\hline Veronica hederifolia L. & Ivy-leaved speedwell & n.r. \\
\hline Veronica persica Poir. & Winter speedwell & n.r. \\
\hline Vicia villosa Roth & Winter vetch & Europe; Asia; North Africa; North America \\
\hline
\end{tabular}

Wild oat is a serious weed that can severely affect the survival and productivity of several crops (Jabran et al., 2010). With regard to specific crop-weed allelopathic interactions, the major information relates to an evaluation of the allelopathic potential of wheat on wild oat. Wheat progenitors (different accessions of Aegilops speltoides Tausch.) were screened for differential seedling allelopathy on the growth of wild oat and lettuce (Hashem and Adkins, 1998; Quader etal., 2001). The evidence showed that wheat plants release a diversity of allelochemicals into the environment. Hydroxamic acid 2,4-dihydroxy-7-methoxy-1,4-benzoxazin-3-one (DIMBOA) and its decomposition product 6-methoxybenzoxazolin-2-one from bread wheat can inhibit root growth and seed germination of wild oat (Pérez, 1990). The mechanism of action of these molecules appears to be related to the combination of cyclic hemiacetal and cyclic hydroxamic acid, which lead to high bioactivity: "as reactions with the electrophilic ring-opened aldehyde form of the hemiacetal and with a multicentered cation generated from $\mathrm{N}-\mathrm{O}$ fission are likely to occur with bionucleophiles" (Macías et al., 2006). 
Table 2 | Overview on the major studies carried out relating to allelochemicals, allelopathic genes, field evaluations, allelopathic bioassays, and breeding programs in wheat.

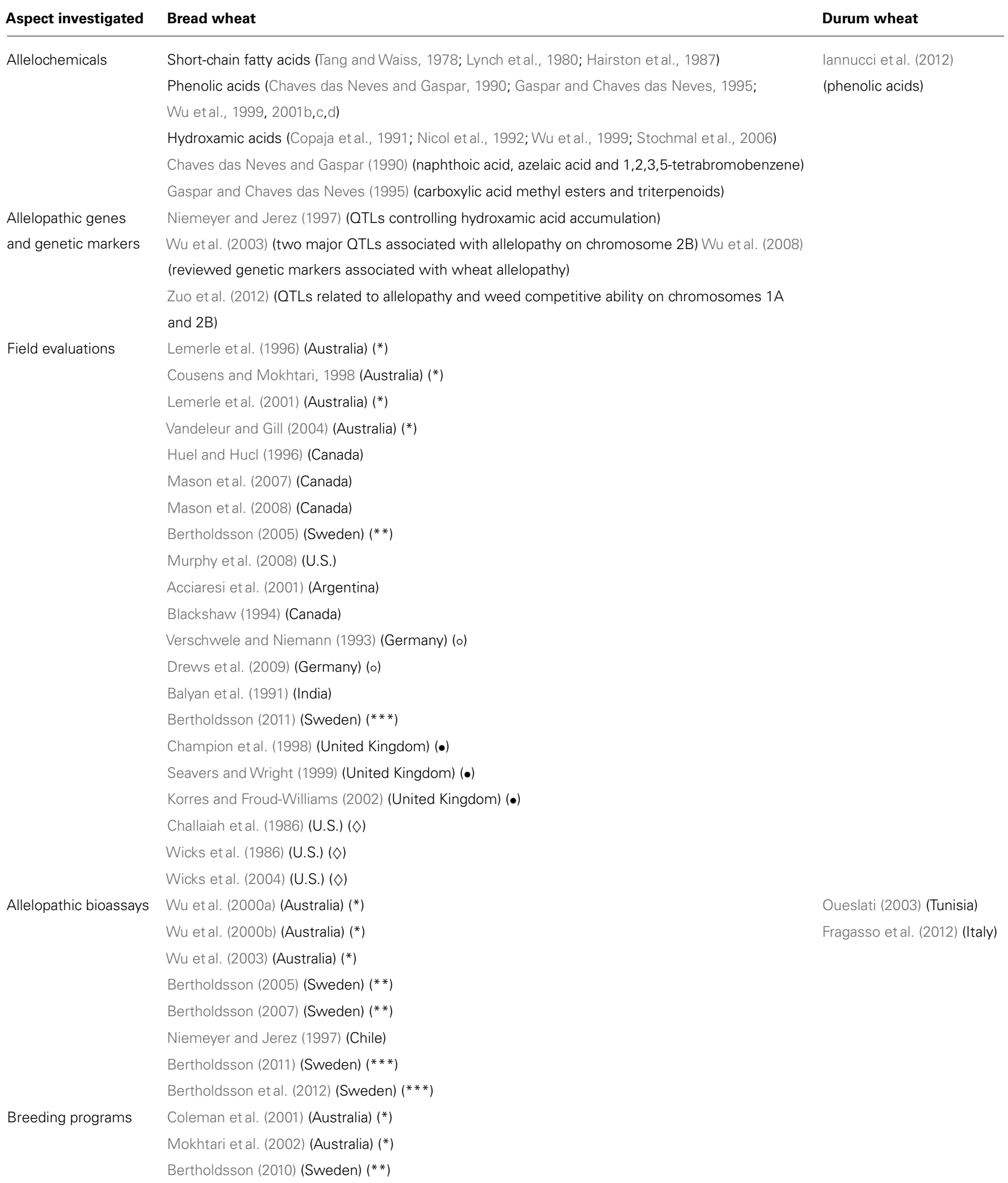

The symbols "*," "**," and "***" denote different phases of the same study, from field evaluations to breeding programs, through the allelopathic bioassays. The symbols " $\diamond, "$ " "o," and "•" indicate studies that used the same germplasm. 
More generally, phenolic compounds are one of the main groups of substances involved in bread wheat allelopathy ( $\mathrm{Wu}$ et al., 2001c). Intriguingly, in studies of wild oat allelopathic potential as a donor plant, phenolic compounds appear to be among the key compounds (Iannucci et al., 2012). Indeed, Fragasso etal. (2012) evaluated the tolerance of wheat to the allelopathic potential of wild oat, and indicated the presence of three potential allelochemicals that belong to this chemical class in the rhizosphere soil of the wild oat: p-coumaric acid, syringaldehyde, and vanillin. It is well-known that phenolic compounds can inhibit root elongation and cell division in plants, and can cause changes to cell ultrastructure, thus interfering with the normal growth and development of the whole plant (Li et al., 2010).

\section{WHEAT ALLELOPATHY: WALKING ON THE GENETIC SIDE}

Information on the allelopathic diversity among crop species and varieties can be dated back to ancient times. However, studies on the genetic variability of allelopathy in crop cultivars as a target for breeding are relatively recent (Belz, 2007). Spruell (1984) performed a first evaluation of the varietal allelopathic activity of Triticum aestivum L. Hundreds of bread wheat genotypes were shown to vary in their allelopathic activities (Wu et al., 2000b, 2001b,d; Zuo et al., 2007; Saffari and Torabi-Sirchi, 2011). Indeed, Wu et al. (2000b) assessed seedling allelopathy of 453 wheat accessions (from 50 countries) against annual ryegrass, showing different levels of inhibition of root growth of ryegrass, ranging from 9.7 to $90.9 \%$ : the continuous distribution of allelopathic activities highlighted among the cultivars indicates a quantitative mode of inheritance. This was confirmed by an assessment of allelopathic compounds produced by the same genotypes. Indeed, in comparison to weakly allelopathic accessions, strongly allelopathic accessions produced significantly higher amounts of allelochemicals (Wu, 2005). Similarly, recently, Fragasso et al. (2012) showed genetic diversity for allelopathic sensitivity among a few varieties of durum wheat.

Direct breeding efforts to improve allelopathy have to date only been reported in rice, where highly allelopathic cultivars are ready to be released (Hu etal., 2008; Kong et al., 2011). Recent technical advances make it possible to locate the genes involved in the control of allelopathic activity and the production of allelochemicals, and to genetically map populations between allelopathic and non-allelopathic accessions, with the final aim being to identify genetic markers associated with allelopathy. In a review on the allelopathic studies in common wheat, $\mathrm{Ma}$ (2005) revised the genotypic differences in the allelopathy of wheat toward weeds and other crops. Some effort has been made to map allelopathy genes in wheat (Niemeyer and Jerez, 1997; Wu etal., 2003) and to identified genetic markers (Wu et al., 2008). Niemeyer and Jerez (1997) used wheat aneuploids and wheat substitution lines to suggest the chromosomal location of genes for hydroxamic acid accumulation (4A, 4B, $4 \mathrm{D}, 5 \mathrm{~B})$ and the multigenic control of this character. Wu et al. (2003) used restriction fragment length polymorphism, amplified fragment length polymorphism, and microsatellite markers, and on chromosome $2 \mathrm{~B}$, they identified two major quantitative trait loci (QTLs) associated with wheat allelopathy. Wu et al. (2007b) reviewed the genetic markers associated with wheat allelopathy and the plant cytochrome P450s that encode the biosynthesis of wheat allelochemicals. Recently, putative QTLs related to allelopathy and the competitive abilities of weeds were detected on chromosomes $1 \mathrm{~A}$ and $2 \mathrm{~B}$ of bread wheat, with possible beneficial insights for the breeding of allelopathic wheat (Zuo et al., 2012). This study also suggested the possibility to identify genetic diversity for these traits also in durum wheat, and the possibility of introgressing the QTLs found in the A and B genomes of bread wheat and durum wheat. Following the common "scale-up" of allelopathic exploitation in crop systems, Table 2 provides an overview of field and laboratory screening protocols, genetic studies, and breeding efforts that have been undertaken to improve allelopathy and competition in wheat. The discovery of additional fine resolution QTLs that control allelopathy in wheat provides the scientific basis for the development of effective molecular markers to be used in marker-assisted selection for allelopathy (Worthington and Reberg-Horton, 2013). In the most recent breeding program, Bertholdsson (2010) used material that originated from a cross between a Swedish cultivar with low allelopathic activity and a Tunisian cultivar with high allelopathic activity. He analyzed the results of a breeding program with bread wheat that determined the efficiency of selection for allelopathy by assessing the ability of the plants to suppress weeds at the field level: highly allelopathic lines obtained from a cross between allelopathic and non-allelopathic parents suppressed weed biomass by $24 \%$ more than the non-allelopathic parent in a dry year $(12 \%$ more in a wet year; Bertholdsson, 2010).

\section{IMPROVING WHEAT COMPETITIVE ABILITY, AND THE CASE FOR DURUM WHEAT}

Wu et al. (2001a) provided an overview of the beneficial and unfavorable effects of allelopathy in bread wheat. In particular, the positive implications concern direct (allelochemicals produced during the life cycle) and indirect (plant residues) weed suppression. On the other hand, the critical effects were: autotoxicity and the wheat yield decline in crops grown as part of short rotations; and the detrimental effects of residues on the growth of other crops (Bennett et al., 2012). Comparing these important implications and the present knowledge briefly summarized here, it appears clear how far we are from being able to manage the beneficial and unfavorable effects of wheat allelopathy.

If the "cons" of durum-wheat allelopathy are clearly represented by this partial and fragmentary scientific knowledge, then the relatively "clean slate" that we have to cope with at present probably represents a "pro," given that in the experimental design we have the opportunity to consider also the recent advances in allelopathy studies: the roles of microbes as targets and mediators of allelopathy in plants (Cipollini etal., 2012), the importance of separating allelopathy from resource competition (He et al., 2012; Iannucci et al., 2012); and the "breeding" (Bertholdsson, 2005, 2007; Worthington and Reberg-Horton, 2013) and "ecological genomics" (Ungerer et al., 2008; Weih et al., 2008) dimensions of the allelopathy phenomena. 


\section{REFERENCES}

Acciaresi, H. A., Chidichimo, H. O., and Sarandón, S. J. (2001). Traits Related to Competitive Ability of Wheat (Triticum aestivum) Varieties against Italian Ryegrass (Lolium multiflorum). Biol. Agric. Hortic. 19, 275-286. doi: 10.1080/01448765.2001.9754930

Afonin, A. N., Greene, S. L., Dzyubenko, N. I., and Frolov, A. N. (eds). (2008). Interactive Agricultural Ecological Atlas of Russia and Neighboring Countries. Economic Plants and their Diseases, Pests and Weeds [Online]. Available at: http://www.agroatlas.ru.

Ahn, J. K., and Chung, I. M. (2000). Allelopathic potential of rice hulls on germination and seedling growth of barnyardgrass. Agron. J. 92, 1162. doi: 10.2134/agronj2000.9261162x

Ahn, J. K., Hahn, S. J., Kim, J. T., Khanh, T. D., and Chung, I. M. (2005). Evaluation of allelopathic potential among rice (Oryza sativa L.) germplasm for control of Echinochloa crus-galli P. Beauv in the field. Crop Protect. 24, 413-419. doi: 10.1016/j.cropro.2004.09.009

Balyan, R. S., Malik, R. K., Panwar, R. S., and Singh, S. (1991). Competitive ability of winter-wheat cultivars with wild oat (Avena ludoviciana). Weed Sci. 39, 154-158.

Barberi, P., Silvestri, N., and Bonari, E. (1997). Weed communities of winter wheat as influenced by input level and rotation. Weed Res. 37, 301-313. doi: 10.1046/j.1365-3180.1997.d01-53.x

Belz, R. G. (2007). Allelopathy in crop/weed interactions - an update. Pest Manag. Sci. 63, 308-326. doi: 10.1002/ps. 1320

Bennett, A. J., Bending, G. D., Chandler, D., Hilton, S., and Mills, P. (2012). Meeting the demand for crop production: the challenge of yield decline in crops grown in short rotations. Biol. Rev. Camb. Philos Soc. 87, 52-71. doi: 10.1111/j.1469185X.2011.00184.X

Bertholdsson, N.-O. (2004). Variation in allelopathic activity over 100 years of barley selection and breeding. Weed Res. 44, 78-86. doi: 10.1111/j.1365-3180.2003.00375.x

Bertholdsson, N.-O. (2005). "Varietal variation in allelopathic activity in wheat and barley and possibilities to use this in breeding," in Proceedings of the 4th World 324 Congress on Allelopathy, Wagga Wagga.

Bertholdsson, N.-O. (2007). Varietal variation in allelopathic activity in wheat and barley and possibilities to use this in breeding. Allelopathy J. 19 , 193-202.

Bertholdsson, N.-O. (2010). Breeding spring wheat for improved allelopathic potential. Weed Res. 50, 49-57. doi: 10.1111/j.13653180.2009.00754.x

Bertholdsson, N.-O. (2011). Use of multivariate statistics to separate allelopathic and competitive factors influencing weed suppression ability in winter wheat. Weed Res. 51, 273-283. doi: 10.1111/j.13653180.2011.00844.x

Bertholdsson, N.-O., Andersson, S. C., and Merker, A. (2012). Allelopathic potential of Triticum spp., Secale spp. and Triticosecale spp. and use of chromosome substitutions and translocations to improve weed suppression ability in winter wheat. Plant Breed. 131, 75-80. doi: 10.1111/j.14390523.2011.01895.x

Blackshaw, R. E. (1994). Differential competitive ability of winter wheat cultivars against downy brome. Agron. J. 86, 649-654. doi: 10 2134/agronj1994.0002196200860004 $0012 \mathrm{x}$

Burgos, N. R., Talbert, R. E., and Mattice, J. D. (1999). Cultivar and age differences in the production of allelochemicals by Secale cereale. Weed Sci. 47, 481-485.

Carrara, M., Comparetti, A., Febo, P., and Orlando, S. (2004). Spatially variable rate of herbicide application on durum wheat in Sicily. Biosyst. Eng. 87, 387-392. doi: 10.1016/j.biosystemseng.2004.01.004 Challaiah, Burnside, O. C., Wicks, G. A. and Johnson, V. A. (1986). Competition between winter-wheat (Triticum aestivum) cultivars and downy brome (Bromus tectorum). Weed Sci. 34 689-693.

Champion, G. T., Froud-Williams, R. J., and Holland, J. M. (1998) Interactions between wheat (Triticum aestivum L.) cultivar, row spacing and density and the effect on weed suppression and crop yield. Ann. Appl. Biol. 133, 443-453. doi: 10.1111/j.1744-7348. 1998.tb05842.x

Chaves das Neves, H. J., and Gaspar, E. M. M. (1990). Identification of active compounds in wheat straw extracts with allelopathic activity by HRGCMS and HRGC-FTIR. J. High Resolut. Chromatogr. 13, 550-554. doi: 10.1002/jhrc. 1240130805

Cipollini, D., Rigsby, C. M., and Barto, E. K. (2012). Microbes as targets and mediators of allelopathy in plants. J. Chem. Ecol. 38, 714-727. doi: 10.1007/s10886-012-0133-7

Coleman, R. K., Gill, G. S., and Rebetzke, G. J. (2001). Identification of quantitative trait loci for traits conferring weed competitiveness in wheat (Triticum aestivum L.). Aust.
J. Agric. Res. 52, 1235-1246. doi: 10.1071/AR01055

Copaja, S. V., Niemeyer, H. M., and Wratten, S. D. (1991). Hydroxamic acid levels in Chilean and British wheat seedlings. Ann. Appl. Biol. 118, 223-227. doi: 10.1111/j.17447348.1991.tb06100.x

Cousens, and Mokhtari. (1998). Seasonal and site variability in the tolerance of wheat cultivars to interference from Lolium rigidum. Weed Res. 38, 301-307. doi: 10.1046/j.13653180.1998.00097.x

De Vita, P., Di Paolo, E., Fecondo, G., Di Fonzo, N., and Pisante, M. (2007a). No-tillage and conventional tillage effects on durum wheat yield, grain quality and soil moisture content in southern Italy. Soil Till. Res. 92, 6978. doi: 10.1016/j.still.2006.01.012

De Vita, P., Nicosia, O. L. D., Nigro, F., Platani, C., Riefolo, C., Di Fonzo, N., et al. (2007b). Breeding progress in morpho-physiological, agronomical and qualitative traits of durum wheat cultivars released in Italy during the 20th century. Eur. J. Agron. 26, 39-53. doi: 10.1016/j.eja.2006. 08.009

Drews, S., Neuhoff, D., and Köpke, U. (2009). Weed suppression ability of three winter wheat varieties at different row spacing under organic farming conditions. Weed Res. 49, 526-533. doi: 10.1111/j.1365-3180.2009.00720.x

FAO. (2011). FAO Agribusiness Handbook: Wheat Flour. Food and Agriculture Organization of the United Nations, 12-18. Available at: https:// www.responsibleagroinvestment.org/ sites/responsibleagroinvestment.org/ files/FAO_Agbiz\%20handbook Wheat\%20Flour.pdf

Fay, P. K., and Duke, W. B. (1977) Assessment of the allelopathic potential in Avena germplasm. Weed Sci. 25, 224-228.

Fragasso, M., Platani, C., Miullo, V., Papa, R., and Iannucci, A. (2012). A bioassay to evaluate plant responses to the allelopathic potential of rhizosphere soil of wild oat (Avena fatua L.): preliminary data. Agrochimica 56, 120-128.

Garcìa-Martìn, A., Lòpez-Bellido, R. J., and Coleto, J. M. (2007). Fertilisation and weed control effects on yield and weeds in durum wheat grown under rain-fed conditions in a Mediterranean climate. Weed Res. 47, 140-148. doi: 10.1111/j.13653180.2007.00547.x

Gaspar, E. M. M., and Chaves das Neves, H. J. (1995). Chemical constituents in allelopathic straw of wheat (Triticum aestivum L.). Allelopathy J. 2, 79-87.
Grimmer, O. P., and Masiunas, J. B. (2005). The weed control potential of oat cultivars. Horttechnology 15, 140-144.

Hairston, J. E., Stanford, J. O., Pope, D. F., and Horneck, D. A. (1987). Soybean-wheat doublecropping; implications from straw management and supplemental nitrogen. Agron. J. 79, 281-286. doi: 10.2134/ agronj1987.0002196200790 $0020021 \mathrm{x}$

Hashem, A., and Adkins, S. W. (1998). Allelopathic effects of Triticum speltoides on two important weeds of wheat. Plant Prot. Q. 13, 33-35.

He, H. B., Wang, H. B., Fang, C. X., Lin, Z. H., Yu, Z. M., and Lin, W. X. (2012). Separation of allelopathy from resource competition using rice/barnyard grass mixedcultures. PLoS ONE 7:e37201. doi: 10.1371/journal.pone.0037201

Hoad, S. P., Bertholdsson, N.-Ø., Neuhoff, D., and Köpke, U. (2012). Approaches to breed for improved weed suppression in organically grown cereals, in Organic Crop Breeding, eds E. T. L. van Bueren and J. R. Myers (Hoboken: Wiley-Blackwell), 61-76.

Hozumi, Y., Nakayama, K., and Yoshida, K. (1974). Allelopathy of wheat, barley and rye on the growth of the rice plant. J. Cent. Agricult. Exp. Stat. 20, 87-102. Available at: http://agris.fao.org/agris-search/ search/display.do?f=1975/JA/JA75018. xml; JA7400281 [Accessed October 27, 2012].

Hu, F., Kong, C., and Chen, X. (2008). "Allelopathic rice: from theory to practice in China," in Book of Abstracts of the 5th World Congress on Allelopathy (Albany: Saratoga Springs), 89.

Huel, D. G., and Hucl, P. (1996). Genotypic variation for competitive ability in spring wheat. Plant Breed. 115, 325-329. doi: 10.1111/j.14390523.1996.tb00927.x

Iannucci, A., Fragasso, M., Platani, C., Narducci, A., Miullo, V., and Papa, R. (2012). Dynamics of release of allelochemical compounds from roots of wild oat (Avena fatua L.). Agrochimica 56, 185-192.

Inderjit, Wardle, D. A., Karban, R., and Callaway, R. M. (2011). The ecosystem and evolutionary contexts of allelopathy. Trends Ecol. Evol. 26, 655-662. doi: 10.1016/j.tree.2011.08.003

Jabran, K., and Farooq, M. (2013). "Implications of potential allelopathic crops in agricultural systems," in Allelopathy, eds Z. A. Cheema, M. Farooq, and A. Wahid (Berlin: Springer), 349-385. 
Jabran, K., Farooq, M., Hussain, M., Hafeez-ur-Rehman, and Ali, M. A. (2010). Wild oat (Avena fatua L.) and canary grass (Phalaris minor Ritz.) management through allelopathy. $J$. Plant Prot. Res. 50, 41-44. doi: 10.2478/v10045-010-0007-3

Jung, W., Kim, K., Ahn, J., Hahn, S., and Chung, I. (2004). Allelopathic potential of rice (Oryza sativa L.) residues against Echinochloa crusgalli. Crop Prot. 23, 211-218. doi: 10.1016/j.cropro.2003.08.019

Kim, K. U., and Shin, D. H. (2003). “The importance of allelopathy in breeding new cultivars," in Weed Management for Developing Countries. FAO Plant Production and Protection Paper No. 120 (addendum 1), ed. R. Labrada (Rome: Food and Agriculture Org), 195-210.

Kong, C.-H., Chen, X.-H., Hu, F., and Zhang, S.-Z. (2011). Breeding of commercially acceptable allelopathic rice cultivars in China. Pest Manag. Sci. 67, 1100-1106.

Korres, N. E., and Froud-Williams, R. J. (2002). Effects of winter wheat cultivars and seed rate on the biological characteristics of naturally occurring weed flora. Weed Res. 42, 417-428. doi: 10.1046/j.13653180.2002.00302.x

Lemerle, D., Verbeek, B., Cousens, R. D., and Coombes, N. E. (1996). The potential for selecting wheat varieties strongly competitive against weeds. Weed Res. 36, 505-513. doi: 10.1111/j.1365-3180.1996.tb01679.x

Lemerle, D., Gill, G. S., Murphy, C. E., Walker, S. R., Cousens, R. D., Mokhtari, S., et al. (2001). Genetic improvement and agronomy for enhanced wheat competitiveness with weeds. Aust. J. Agric. Res. 52, 527-548. doi: 10.1071/AR00056

Li, Z. H., Wang, Q., Ruan, X., Pan, C. D., and Jiang, D. A. (2010). Phenolics and plant allelopathy. Molecules 15, 8933-8952. doi: 10.3390/molecules15128933

Lynch, J. M., Gunn, K. B., and Panting, L. M. (1980). On the concentration of acetic acid in straw and soil. Plant Soil 56, 93-98. doi: 10.1007/BF02197956

Ma, Y. (2005). Allelopathic studies of common wheat (Triticum aestivum L.). Weed Biol. Manag. 5, 93-104. doi: $\quad 10.1111 /$ j.1445-6664.2005.00 164.x

Macías, F. A., Marín, D., Oliveros-Bastidas, A., Chinchilla, D., Simonet, A. M., and Molinillo, J. M. G. (2006). Isolation and synthesis of allelochemicals from gramineae: benzoxazinones and related compounds. J. Agric. Food Chem. 54, 991-1000. doi: 10.1021/jf050896x
Mason, H., Goonewardene, L., and Spaner, D. (2008). Competitive traits and the stability of wheat cultivars in differing natural weed environments on the northern Canadian Prairies. J. Agric. Sci. 146 21-33. doi: 10.1017/S00218596070 07319

Mason, H. E., Navabi, A., Frick, B. L. O'Donovan, J. T., and Spaner, D. M. (2007). The weed-competitive ability of Canada western red spring wheat cultivars grown under organic management. Crop Sci. 47, 1167. doi: 10.2135/cropsci2006.09.0566

Mokhtari, S., Galwey, N. W., Cousens, R. D., and Thurling, N. (2002) The genetic basis of variation among wheat F3 lines in tolerance to competition by ryegrass (Lolium rigidum). Euphytica 124, 355-364. doi: 10.1023/A:1015752021568

Murphy, K. M., Dawson, J. C., and Jones, S. S. (2008). Relationship among phenotypic growth traits, yield and weed suppression in spring wheat landraces and modern cultivars. Field Crops Res. 105, 107-115. doi: 10.1016/j.fcr.2007.08.004

Nicol, D., Copaja, S. V., Wratten, S. D., and Niemeyer, H. M. (1992). A screen of worldwide wheat cultivars for hydroxamic acid levels and aphid antixenosis. Ann. Appl. Biol. 121, 11-18. doi: 10.1111/j.17447348.1992.tb03982.x

Niemeyer, H. M., and Jerez, J. M. (1997). Chromosomal location of genes for hydroxamic acid accumulation in wheat using wheat aneuploids and wheat substitution lines. Heredity 79, 10-14. doi: 10.1038/hdy.1997.117 Olofsdotter, M., Jensen, L. B., and Courtois, B. (2002). Improving crop competitive ability using allelopathy - an example from rice. Plant Breed. 121, 1-9. doi: 10.1046/j.14390523.2002.00662.x

Oueslati, O. (2003). Allelopathy in two durum wheat (Triticum durum L.) varieties. Agric. Ecosyst. Environ. 96, 161-163. doi: 10.1016/S01678809(02)00201-3

Pérez, F. J. (1990). Allelopathic effect of hydroxamic acids from cereals on Avena sativa and A. fatua. Phytochemistry 29, 773-776. doi: 10.1016/00319422(90)80016-A

Prohens, J. (2011). Plant breeding: a success story to be continued thanks to the advances in genomics. Front. Plant Sci. 2:51. doi: 10.3389/fpls.2011.00051

Putnam, A. R., and Duke, W. B. (1974). Biological suppression of weeds: evidence for allelopathy in accessions of cucumber. Science 185, 370-372. doi: $10.1126 /$ science. 185.4148 .370
Quader, M., Daggard, G., Barrow, R., Walker, S., and Sutherland, M. W. (2001). Allelopathy, DIMBOA production and genetic variability in accessions of Triticum speltoides. J. Chem. Ecol. 27, 747-760. doi: 10.1023/A:1010354019573

Reberg-Horton, S. C., Burton, J. D., Danehower, D. A., Ma, G., Monks, D. W., Murphy, J. P., et al. (2005). Changes over time in the allelochemical content of ten cultivars of rye (Secale cereale L.). J. Chem. Ecol. 31, 179-193. doi: 10.1007/s10886-0050983-3

Saffari, M., and Torabi-Sirchi, M. H. (2011). Allelopathic effects of straw extract from two native Iranian wheat varieties on the growth of two corn varieties (Single Cross 647, 704). Am. Eurasian J. Agric. Environ. Sci. 10, 133-139.

Seal, A. N., Pratley, J. E., Haig, T., and Lewin, L. G. (2004). Screening rice varieties for allelopathic potential against arrowhead (Sagittaria montevidensis), an aquatic weed infesting Australian Riverina rice crops. Aust. J. Agric. Res. 55, 673-680. doi: 10.1071/AR03238

Seavers, G. P., and Wright, K. J. (1999). Crop canopy development and structure influence weed suppression. Weed Res. 39, 319-328. doi: 10.1046/j.1365-3180.1999.00148.x

Soltani, N., Shropshire, C., and Sikkema, P. H. (2011). Sensitivity of durum wheat (Triticum turgidum) to various postemergence herbicides. Agric. Sci. 2, 451-456.

Spruell, J. A. (1984). Allelopathic potential of wheat accessions. Diss. Abstr. Int. B Sci. Eng. 45, 1102B.

Stochmal, A., Kus, J., Martyniuk, S., and Oleszek, W. (2006). Concentration of benzoxazinoids in roots of field-grown wheat (Triticum aestivum L.) varieties. J. Agric. Food Chem. 54, 1016-1022. doi: 10.1021/jf050899+

Tang, C. S., and Waiss, A. C. Jr. (1978). Short-chain fatty acids as growth inhibitors in decomposing wheat straw. J. Chem. Ecol. 4, 225232. doi: 10.1007/BF00988057

Toure, A., Rodenburg, J., Saito, K., Oikeh, S., Futakuchi, K., Gumedzoe, D., et al. (2011). Cultivar and weeding effects on weeds and rice yields in a degraded upland environmen of the coastal savanna. Weed Technol. 25, 322-329. doi: 10.1614/WT-D-10 00172.1

Ungerer, M. C., Johnson, L. C., and Herman, M. A. (2008). Ecological genomics: understanding gene and genome function in the natural environment. Heredity 100, 178-183. doi: 10.1038/sj.hdy.6800992
United Nations. (2006). Statistics Division, Statistical Yearbook 2005-2006. Rome: Food and Agricultural Organization.

Vandeleur, R. K., and Gill, G. S. (2004). The impact of plant breeding on the grain yield and competitive ability of wheat in Australia. Aust. J. Agric. Res. 55, 855-861. doi: 10.1071/AR 03136

Verschwele, A., and Niemann, P. (1993). "Indirect weed-control by selection of wheat cultivars," in Proceedings of the 8th European Weed Research Society Symposium, ed. T. Eggers (Braunschweig: European Weed Research Society), 799-806.

Weih, M., Didon, U. M. E., RönnbergWästljung, A.-C., and Björkman, C. (2008). Integrated agricultural research and crop breeding: allelopathic weed control in cereals and long-term productivity in perennial biomass crops. Agric. Syst. 97, 99107. doi: 10.1016/j.agsy.2008.02.009

Weir, T. L., Park, S.-W., and Vivanco, J. M. (2004). Biochemical and physiological mechanisms mediated by allelochemicals. Curr. Opin. Plant Biol. 7, 472-479. doi: 10.1016/j.pbi.2004.05.007

Wicks, G. A., Nordquist, P. T., Baenziger, P. S., Klein, R. N., Hammons, R. H., and Watkins, J. E. (2004). Winter wheat cultivar characteristics affect annual weed suppression. Weed Technol. 18, 988-998. doi: 10.1614/WT03-158R1

Wicks, G. A., Ramsel, R. E., Nordquist, P. T., Schmidt, J. W., and Challaiah (1986). Impact of wheat cultivars on establishment and suppression of summer annual weeds. Agron. J. 78, 59-62.

Wolfe, M. S., Baresel, J. P., Desclaux, D., Goldringer, I., Hoad, S., Kovacs, G., et al. (2008). Developments in breeding cereals for organic agriculture. Euphytica 163, 323-346. doi: 10.1007/s10681-008-9690-9

Worthington, M., and Reberg-Horton, C. (2013). Breeding cereal crops for enhanced weed suppression: optimizing allelopathy and competitive ability. J. Chem. Ecol. 39, 213-231. doi: 10.1007/s10886-013-0247-6

Wu, H. (2005). "Molecular approaches in improving wheat allelopathy," in Proceedings of the 4th World Congress on Allelopathy, Wagga Wagga.

Wu, H., An, M., Liu, D. L., Pratley, J., and Lemerle, D. (2008). "Recent advances in wheat allelopathy," in Allelopathy in Sustainable Agriculture and Forestry, eds R. S. Zeng, A. U. Mallik, and S. M. Luo (New York: Springer), 235-254. Available at: http://www. springerlink.com/content/m5816676330722 
63/abstract/ [accessed October 20, 2012].

Wu, H., Pratley, J., Lemerle, D., An, M., and Liu, D. (2007a). Autotoxicity of wheat (Triticum aestivum L.) as determined by laboratory bioassays. Plant Soil 296, 85-93. doi: 10.1007/s11104007-9292-7

Wu, H., Pratley, J., Lemerle, D., An, M., and Liu, D. L. (2007b). Modern genomic approaches to improve allelopathic capability in wheat (Triticum aestivum L.). Allelopathy J. 19, 97-108.

Wu, H., Pratley, J., Lemerle, D., and Haig, T. (1999). Crop cultivars with allelopathic capability. Weed Res. 39, 171-180. doi: 10.1046/j.13653180.1999.00136.x

Wu, H., Pratley, J., Lemerle, D., and Haig, T. (2000a). Laboratory screening for allelopathic potential of wheat (Triticum aestivum) accessions against annual ryegrass (Lolium rigidum). Aust. J. Agric. Res. 51, 259-266. doi: 10.1071/AR98183

Wu, H., Pratley, J. E., Lemerle, D., and Haig, T. (2000b). Evaluation of seedling allelopathy in 453 wheat (Triticum aestivum) accessions against annual ryegrass (Lolium rigidum) by the equalcompartment agar method. Aust. J. Agric. Res. 51, 937-944. doi: 10.1071/ AR00017

Wu, H., Pratley, J., Lemerle, D. and Haig, T. (2001a). Allelopathy in wheat (Triticum aestivum) Ann. Appl. Biol. 139, 1-9. doi: 10.1111/j.1744-7348.2001.tb00124.x

Wu, H., Pratley, J. E., Lemerle, D., and An, M. (2001b). Allelochemicals in wheat (Triticum aestivum L.): production and exudation of 2,4-dihydro-7methoxy-1,4-benzoxazin-3-one. J. Chem. Ecol. 27, 1691-1700. doi: 10.1023/A:1010422727899

Wu, H., Haig, T., Pratley, J., Lemerle, D., and An, M. (2001c). Allelochemicals in wheat (Triticum aestivum L.): variation of phenolic acids in shoot tissues. J. Chem. Ecol. 27, 125-135. doi: 10.1023/A:10056762 18582

Wu, H., Haig, T., Pratley, J., Lemerle, D., and An, M. (2001d). Allelochemicals in wheat (Triticum aestivum
L.): cultivar difference in the exudation of phenolic acids. J. Agric. Food Chem. 49, 3742-3745. doi: 10.1021/jf010111x

Wu, H., Pratley, J., Ma, W. and Haig, T. (2003). Quantitative trait loci and molecular markers associated with wheat allelopathy. Theor. Appl. Genet. 107, 1477-1481. doi: 10.1007/s00122003-1394-x

Zuo, S., Liu, G., and Li, M (2012). Genetic basis of allelopathic potential of winter wheat based on the perspective of quantitative trait locus. Field Crops Res. 135, 67-73. doi: 10.1016/j.fcr.2012. 07.005

Zuo, S., Ma, Y., and Inanaga, S. (2007). Allelopathy variation in dryland winter wheat (Triticum aestivum L.) accessions grown on the Loess Plateau of China for about fifty years. Genet. Resour. Crop Evol. 54, 13811393. doi: 10.1007/s10722-006 9123-3

Conflict of Interest Statement: The authors declare that the research was conducted in the absence of any commercial or financial relationships that could be construed as a potential conflict of interest.

Received: 25 June 2013; accepted: 03 September 2013; published online: 24 September 2013.

Citation: Fragasso M, Iannucci A and Papa $R$ (2013) Durum wheat and allelopathy: toward wheat breeding for natural weed management. Front. Plant Sci. 4:375. doi: 10.3389/fpls.2013.00375 This article was submitted to Crop Science and Horticulture, a section of the journal Frontiers in Plant Science.

Copyright (C) 2013 Fragasso, Iannucci and Papa. This is an open-access article distributed under the terms of the Creative Commons Attribution License (CC BY).

The use, distribution or reproduction in other forums is permitted, provided the original author(s) or licensor are credited and that the original publication in this journal is cited, in accordance with accepted academic practice. No use, distribution or reproduction is permitted which does not comply with these terms. 